\title{
A study to know clinical characteristics and outcome of obstetrics patients requiring ICU admission
}

\author{
Pratibha Garg*, Urmila Tripathi
}

Department of Obstetrics and Gynecology, Gajra Raja Medical College, Gwalior, Madhya Pradesh, India

Received: 29 May 2018

Accepted: 04 June 2018

*Correspondence:

Dr. Pratibha Garg,

E-mail: drgargpratibha@gmail.com

Copyright: (C) the author(s), publisher and licensee Medip Academy. This is an open-access article distributed under the terms of the Creative Commons Attribution Non-Commercial License, which permits unrestricted non-commercial use, distribution, and reproduction in any medium, provided the original work is properly cited.

\begin{abstract}
Background: Pregnancy poses unique consideration for critical care and it is imperative that obstetrician and other members of health care team have a working knowledge of these factors because these are women are usually young and in good health, their prognosis should be better than that of many other patients admitted to an intensive care.

Methods: The present study was conducted in the Department of Obstetrics and Gynaecology, Gaja Raja Medical College and associate Kamla raja Hospital, Gwalior in the ICU from Oct. 14 to Oct. 15.

Results: 678 obstetric women were admitted into the ICU of Kamla Raja Hospital, over a period of 1 year study period. Maximum number of patients belong to age group 21-25 years (54.8\%), $398(58.7 \%)$ patients were uneducated, $343(50.59 \%)$ came directly to Kamla Raja Hospital. 362 (53.39\%) belongs to urban area. The mean length of stay in ICU was 3 days. Maximum number of patients were postpartum 580 (85.55\%). According to mode of delivery maximum number of patients 348 (51.33\%) underwent LSCS. Most common obstetric indication for admission in ICU was hypertensive disorder of pregnancy 472 (69.61\%). Most common medical indication was severe anaemia $128(18.87 \%)$. Various type intervention like pulse oxymetry, O2 inhalation, BT, nebulisation and ventilation were done in ICU according to patients need. 43 maternal death happened during the study period with most common cause was cardiorespiratory arrest $9(1.32 \%)$ and pulmonary edema $8(1.17 \%)$.

Conclusions: Establishment of a dedicated obstetric ICU at tertiary care centre with knowledge familiarity, experience and expertise of an obstetrician and a special team would be best place to monitor and treat the critically ill obstetric patients which will reduce the maternal morbidity and mortality.
\end{abstract}

Keywords: Anemia, Hypertensive disorder of pregnancy, ICU, LSCS, Obstetric haemorrhage

\section{INTRODUCTION}

The principles behind the pathogenesis and treatment of critical care illness began to take shape in 1980s in the UK, joint training posts in critical care medicine were introduced in $1986 .{ }^{1}$

Since late 1980s and 1990s, dedicated US, obstetrics intensive care has become well established in same maternity units in the South Africa and the Netherlands. ${ }^{2-4}$
Obstetric medicine is unique and complicated obstetric medicine is different from the general medicine because of various physiological changes occurring in pregnancy and only an experienced obstetrician who has good knowledge of obstetric medicine can interpret and understand complex conditions in pregnancy.

The threshold of an insult required for ICU admission is low in obstetric patients compared to nonpregnant population. The threshold for ventilator support also is low in pregnancy. 


\section{METHODS}

The study was conducted in the Department of Obstetrics and Gynaecology, Gajra Raja Medical College and associate Kamla Raja Hospital, Gwalior in Obstetric ICU from October 2014 to October 2015 over a period of 1 year. Each patient's records were reviewed and detailed.

\section{Inclusion criteria}

- All pregnant women irrespective of the duration and site of pregnancy.

- Women during first 6 weeks of postpartum period irrespective of mode of delivery.

- Women within 6 weeks of abortion.

- Obstetrics patients with preexisting medical disorders requiring admission to ICU.

\section{Exclusion criteria}

- All non-obstetric patients.

The primary objective of present study was to review the characteristics and outcome of the obstetric patients admitted to ICU over one year for obstetric related causes.

\section{RESULTS}

In Table 1 the maximum number of patients in the study were in the age group of 21-25 years (54.87\%).

Table 1: Age distribution of patient admitted to ICU.

\begin{tabular}{|lll|}
\hline Age group (years) & No. of cases & Percentage \\
\hline $18-20$ & 68 & 10.03 \\
\hline $21-25$ & 372 & 54.87 \\
\hline $26-30$ & 176 & 25.95 \\
\hline $31-35$ & 46 & 6.79 \\
\hline$>35$ & 16 & 2.36 \\
\hline Total & 376 & 100 \\
\hline
\end{tabular}

In the study 62 patients were above the age of 30 years of age $(9.1 \%)$. According to Table 2 out of 678 patients, 398 $(58.7 \%)$.

Table 2: Education status of patients admitted to the obstetric ICU.

\begin{tabular}{|lll|}
\hline Education & No. of cases & Percentage \\
\hline Educated & 280 & 41.30 \\
\hline Uneducated & 398 & 58.70 \\
\hline Total & 678 & 100 \\
\hline
\end{tabular}

As per Table 3 out of $678,343(50.59 \%)$ came directly to Kamla Raja Hospital and $335(49.41 \%)$ were referred from primary health centres, district hospitals and private hospitals. were uneducated and 280 (41.3\%) were educated.
Table 3: Direct/referral status of patients admitted to ICU.

\begin{tabular}{|lll|}
\hline Direct/Referral & No. of cases & Percentage \\
\hline Direct & 343 & 50.59 \\
\hline Referral & 335 & 49.41 \\
\hline Total & 678 & 100 \\
\hline
\end{tabular}

In Table 4 out of $678,316(40.61 \%)$ belongs to rural area and $362(53.39 \%)$ belong to the urban area.

Table 4: Locality of patients admitted to ICU

\begin{tabular}{|lll|}
\hline Locality & No. of cases & Percentage \\
\hline Rural & 316 & 40.61 \\
\hline Urban & 362 & 53.39 \\
\hline Total & 678 & 100 \\
\hline
\end{tabular}

According to Table 5 the mean length of stay in ICU was 3 days with a range of 1-12 days. 564 patients (83.18\%) stayed for 2-4 days and $37(5.46 \%)$ stayed for 5-7 days, 4 $(0.58 \%)$ stayed for $8-10$ days, 69 patients $(10.27 \%)$ stayed for $<1$ day and 4 patients $(0.58 \%)$ stayed for $>11$ days.

Table 5: Duration of stay of patients admitted to obstetric ICU.

\begin{tabular}{|lll|}
\hline Duration (days) & No. of cases & Percentage \\
\hline$\leq 1$ & 69 & 10.2 \\
\hline $2-4$ & 564 & 83.18 \\
\hline $5-7$ & 37 & 5.46 \\
\hline $8-10$ & 4 & 0.58 \\
\hline$\geq 11$ & 4 & 0.58 \\
\hline Total & 678 & 100 \\
\hline
\end{tabular}

As per Table 6, out of $678,580(85.55 \%)$ patients were postpartum, $77(11.36 \%)$ were antepartum and the remaining $21(3.09 \%)$ were postabortal.

Table 6: Status of pregnancy in patients admitted to obstetric ICU.

\begin{tabular}{|lll|}
\hline Locality & No. of cases & Percentage \\
\hline Potpartum & 580 & 85.55 \\
\hline Antepartum & 77 & 11.36 \\
\hline Postabortal & 21 & 3.09 \\
\hline Total & 678 & 100 \\
\hline
\end{tabular}

As per Table 7 out of $678,348(51.33 \%)$ patients underwent LSCS, 158 (23.3\%) delivered vaginally, 48 (7.08\%) underwent laparotomy, $23(3.39 \%)$ patients head suction and evacuation and $18(2.66 \%)$ patients had cesarean hysterectomy. $5(0.74 \%)$ patients had hysterotomy and 1 patient was there for MTP for some medical reason. The patients who were antepartum and did not undergo any mode of delivery were $77(11.36 \%)$. According to Table 8 the most common indications for ICU admission was hypertensive disorder of pregnancy 
$472(69.61 \%)$ of which eclampsia were most common i.e. $166(24.48 \%)$. The second most common indication was obstetric haemorrhage $172(25.36 \%)$. Ectopic pregnancy was $34(5.01 \%)$, PPH were $37(5.45 \%)$, 40 were placenta previa $(5.89 \%), 5$ patients $(0.73 \%)$ were with retained placenta.

Table 7: Mode of delivery of patients admitted to obstetric ICU.

\begin{tabular}{|lll|}
\hline Locality & No. of cases & Percentage \\
\hline LSCS & 348 & 51.33 \\
\hline Vaginal delivery & 158 & 23.30 \\
\hline Laparotomy & 48 & 7.08 \\
\hline Suction and evacuation & 23 & 3.39 \\
\hline Cesarean hysterectomy & 18 & 2.66 \\
\hline Hysterotomy & 5 & 0.74 \\
\hline MTP & 1 & 0.14 \\
\hline None & 77 & 11.36 \\
\hline Total & 678 & 100 \\
\hline
\end{tabular}

Table 8: Obstetric indications of patients admitted to obstetric ICU.

\begin{tabular}{|c|c|c|}
\hline Obstetric indications & $\begin{array}{l}\text { No. of cases } \\
(n=678)\end{array}$ & Percentage \\
\hline $\begin{array}{l}\text { Hypertensive disorders } \\
\text { of pregnancy }\end{array}$ & 472 & \\
\hline Eclampsia & 166 & 24.48 \\
\hline Preeclampsia & 30 & 4.42 \\
\hline Obst. HTN & 66 & 9.7 \\
\hline Obstetric haemorrhage & 172 & \\
\hline PPH & 37 & 5.45 \\
\hline Placenta previa & 40 & 5.89 \\
\hline Abruptio placenta & 12 & 1.76 \\
\hline Retained placenta & 05 & 0.73 \\
\hline Placenta accrete & 08 & 1.17 \\
\hline Ectopic pregnancy & 34 & 5.01 \\
\hline Ruptured uterus & 15 & 2.21 \\
\hline Uterine inversion & 5 & 0.73 \\
\hline H. mole & 6 & 0.88 \\
\hline Incomplete abortion & 10 & 1.47 \\
\hline Others & 7 & \\
\hline Septicemia & 3 & 0.44 \\
\hline DIC & 1 & 0.14 \\
\hline Psychosis & 3 & 0.44 \\
\hline Observations & 16 & \\
\hline Maternal tachycardia & 6 & 0.88 \\
\hline Hypotension & 5 & 0.73 \\
\hline Haematuria & 2 & 0.29 \\
\hline Bradyponea & 1 & 0.14 \\
\hline Abdominal distension & 2 & 0.29 \\
\hline
\end{tabular}

Rupture uterus were $15(2.21 \%)$, H. mole were 6 $(0.88 \%), 10(1.47 \%)$ patients were admitted to ICU with incomplete abortion with very severe anaemia. Other indications were septicemia, DIC, psychosis 7 (1.83\%). The remaining were for observation $16(2.35 \%)$ patients for causes like maternal tachycardia, hypotension, haematuria, bradyponea, abdominal distension.

Table 9: Medical indications of patients admitted to ICU.

\begin{tabular}{|c|c|c|}
\hline & $\begin{array}{l}\text { No. of } \\
\text { cases }\end{array}$ & Percentage \\
\hline Hematological & 132 & \\
\hline Severe anaemia & 128 & 18.87 \\
\hline Shock & 4 & 0.58 \\
\hline Neurological disease & 1 & \\
\hline Aneurysm & 1 & 0.14 \\
\hline Respiratory disease & 39 & \\
\hline Asthma & 5 & 0.73 \\
\hline Pulmonary tuberculosis & 3 & 0.44 \\
\hline Pulmonary edema & 18 & 2.65 \\
\hline $\begin{array}{l}\text { Lower respiratory tract } \\
\text { infection }\end{array}$ & 11 & 1.62 \\
\hline $\begin{array}{l}\text { Acute respiratory } \\
\text { distress syndrome }\end{array}$ & 2 & 0.29 \\
\hline Hepatorenal disease & 12 & \\
\hline Acute renal failure & 4 & 0.58 \\
\hline Hepatitis & 6 & 0.88 \\
\hline $\begin{array}{l}\text { Hepatic } \\
\text { encephalopathy }\end{array}$ & 2 & 0.29 \\
\hline GI disease & 1 & \\
\hline Pancreatitis & 0 & \\
\hline Perforation peritonitis & 1 & 0.14 \\
\hline Others & 36 & \\
\hline DM & 7 & 1.03 \\
\hline Malaria & 8 & 1.17 \\
\hline Anaphylaxis & 5 & 0.73 \\
\hline Heart disease & 16 & 2.35 \\
\hline
\end{tabular}

As per Table 9 most common indication for obstetric ICU admission was severe anaemia due to iron deficiency 128 $(18.87 \%)$. Second most common medical indication was respiratory disease $39(5.75 \%)$. Hepatorenal disease accounts for 12 patients i.e. $1.76 \%$. Others were diabetes mellitus $7(1.03 \%)$, malaria $8(1.17 \%)$ and anaphylaxis 5 $(0.73 \%)$ and heart disease $16(2.35 \%)$.

Table 10: Intervention of patients admitted to obstetric ICU.

\begin{tabular}{|lll|}
\hline Oximetry & No. of cases & Percentage \\
\hline $\mathrm{O}_{2}$ & 570 & 84.07 \\
\hline Nebulisation & 93 & 13.71 \\
\hline $\mathrm{BT}$ & 545 & 80.38 \\
\hline Ionotropic drugs & 75 & 11.06 \\
\hline Ventilator & 12 & 1.76 \\
\hline
\end{tabular}

According to Table 10, $100 \%$ patients were on pulse oximetry for monitoring and basic vitals and oxygen saturation whereas $570(84.07 \%)$ patients needed oxygen supplementation. $545(80.38 \%)$ required BT and ionotropic supports were given to $75(11.06 \%)$ whereas 
$93(13.71 \%)$ patients required nebulisation, $12(1.76 \%)$ patients needed ventilatory support.

Table 11: Outcome of patients admitted to obstetric ICU.

\begin{tabular}{|lll|}
\hline Outcome & No. of cases & Percentage \\
\hline Shift to ward & 609 & 89.82 \\
\hline Transfer out & 24 & 3.53 \\
\hline Morbidity & 43 & 6.34 \\
\hline LAMA & 2 & 0.29 \\
\hline Total & 678 & 100 \\
\hline
\end{tabular}

As per Table 11, out of 678 patients, 609 (89.82\%) were shifted to general ward and discharged, 24 (3.53\%) were transferred out to other departments of our hospital whereas $43(6.34 \%)$ mortalities occurred in obstetric ICU, 2 patients $(0.29 \%)$ left against medical advice.

\section{Table 12: Causes of maternal death of patients} admitted in obstetric ICU.

\begin{tabular}{|c|c|c|}
\hline & No. of cases & Percentage \\
\hline Cardiorespiratory arrest & 9 & 1.32 \\
\hline Pulmonary edema & 8 & 1.17 \\
\hline $\begin{array}{l}\text { Haemorrhagic shock } \\
\text { with CR arrest }\end{array}$ & 3 & 0.44 \\
\hline Multiorgan failure & 3 & 0.44 \\
\hline $\begin{array}{l}\text { Pulmonary } \\
\text { thromboembolism }\end{array}$ & 7 & 1.03 \\
\hline $\begin{array}{l}\text { Congestive cardiac } \\
\text { failure }\end{array}$ & 5 & 0.73 \\
\hline Hepatorenal failure & 1 & 0.14 \\
\hline $\begin{array}{l}\text { Sudden postpartum } \\
\text { collapse }\end{array}$ & 5 & 0.73 \\
\hline Aspiration syndrome & 1 & 0.14 \\
\hline Septic shock & 0 & 0 \\
\hline Cardiogenic shock & 1 & 0.14 \\
\hline
\end{tabular}

According to Table 12, out of 678,43 mortalities occurred in obstetric ICU with causes i.e. cardiorespiratory arrest, pulmonary edema, hemorrhagic shock with cardiorespiratory arrest, multiorgan failure, pulmonary thromboembolism, congestive cardiac failure, hepatorenal failure, sudden postpartum collapse, aspiration syndrome, cardiac shock were $9(1.32 \%), 8$ (1.17\%), 3 (0.44\%), 3 (0.44\%), 7 (1.03\%), 5 (0.73\%), 1 $(0.14 \%), 5(0.73 \%), 1(0.14 \%), 1(0.14 \%)$.

\section{DISCUSSION}

The maximum number of patients in present study 21-25 years of age $(54.8 \%) .62$ patients were above the age of 30 years.

Reiz $U$ et al reported a worse prognosis aged $<20$ years deceased. Waterson et al6 found that $>34$ years was an independent predictor for maternal mortality in obstetric ICU patients. ${ }^{5}$
In present study out 678 patients 398 (58.71\%) were uneducated, $335(49.41 \%)$ were referral cases. Level of education, rural/urban background and poor antenatal care have been found to have a considerable effect on obstetric complications and outcome.

Waterson et al observed a worse prognosis for women of lower socio-economic conditions in UK. Okonofua in Africa reported that low socioeconomic status and poor antenatal care have considerable effects on obstetric complications and outcome..$^{6,7}$

In present study $100 \%$ patients required pulse oxymetry for close monitoring of pulse, $\mathrm{BP}$, respiratory rate and oxygen saturation, whereas $570(84.07 \%)$ needed oxygen supplementation. $545 \quad(80.38 \%)$ required blood transfusion in the form of packed cell, WBR, blood products like FFP, PRP etc. Ionotropics were given to 75 $(11.06 \%)$ patients and nebulisation was required by 93 $(13.71 \%)$ of cases. Ventilatory support was given to 12 $(1.76 \%)$ In their study Kilpatric SJ et al observed that hemodynamic and respiratory complications, needing ionotropic or ventilation support remain the most common reasons for ICU admission and need for support may predict poor outcome. Graham et al reported that $60 \%$ patients received mechanical ventilation. ${ }^{8-10}$

In present study the mean length of stay in ICU as 3 days with a range of 1-12 days.

The mean duration of ventilation and ICU stays as apparently less in present study than others which could have attributed to higher mortality rate in present study. ${ }^{10-12}$

In present study most, common indication for ICU admission was hypertensive disorder of pregnancy, 472 $(69.61 \%)$ of which eclampsia $166 \quad(24.48 \%)$, preeclampsia $30(4.42 \%)$ and gestational hypertension 66 $(9.7 \%)$.

The second most common was obstetric hemorrhage of which PPH were 37 (5.45\%), placenta previa 40 (5.8\%), abruptio placentae $12(1.76 \%)$, retained placenta 5 $(0.73 \%)$, placenta accreta, $8(1.17 \%)$, ectopic pregnancy $34(5.01 \%)$, rupture uterus $15(2.21 \%)$, uterine inversion $5(0.73 \%)$, H. mole $6(0.88 \%), 10$ incomplete abortion i.e. $1.47 \%$. The other were septicemia, DIC, psychosis 7 $(1.83 \%)$. The remaining $16(2.35 \%)$ patients were for observation.

Hazelgrove and Coworkers reported an analysis of South West Thames data house where the primary reason for admission was hypertensive disorder of pregnancy $(39.5 \%)$ followed by massive hemorrhage $(33.3 \%){ }^{13}$

Umo-Etuk et al in a five-year review reported pregnancy induced hypertension as the major reason for ICU admission. ${ }^{14}$ 
Most common medical indication for admission was severe anaemia $128(18.87 \%)$. Second most common was respiratory disease respiratory disease $39(5.75 \%)$, hepatorenal disease account for 12 patients $(1.76 \%)$.

According to Munner et al medical disease associated with pregnancy differ according to socio economic level and healthcare facilities for pregnant and postpartum women. Consequently malaria, viral hepatitis, venous thrombosis and poisoning in that order were the most diagnosed illness in India, whereas in United States of America, the most frequently diagnosed illness after placental anomalies were myocarditis, sepsis and drug abuse. ${ }^{15}$ In present study out 678 patients $348(51.33 \%)$ underwent LSCS, 158 (23.305), delivered vaginally, 48 (7.08\%) underwent laparoscopy, $23(3.39 \%)$ had S and E, $18(2.66 \%)$ underwent cesarean hysterectomy, $5(0.74 \%)$ had hysterotomy, 1 had MTP. 77 (11.36\%) patients did not undergo any mode of delivery.

Studies done so far report antepartum admission (Yuel VI et al and Ashraf $\mathrm{N}$ et al) and delivery admission (on the day of delivery) (Wanderrer JP et al, Stavens TA et al). According to Zwart cesarean delivery is an adjusted risk factors for ICU admission. ${ }^{16-20}$

In present study out of $678,609(89.82 \%)$ patients were shifted to general ward and discharged. 24 (3.53\%) cases transferred out to the other department of our hospitals such as medicine department whereas 43 (6.34\%) mortalities occurred in obstetric ICU. $2(0.29 \%)$ patients left again medical advice.

The mortality rate of our patients admitted in obstetric ICU was $6.34 \%$ which is similar to that reported by Hong Kong by Tang et al in 1997 (6\%). 2.3\% mortality rate was reported by Mahatte et al and Jenkins et al. ${ }^{21-23}$

\section{CONCLUSION}

Establishment of a dedicated obstetric ICU at a tertiary care centre with knowledge at a tertiary care centre with knowledge familiarity, experience and expertise of an obstetrician and special team would be best place to monitor and treat critical ill obstetric patients which will reduce maternal obstetric morbidity and mortality.

The meticulous adaptation of safe motherhood initiative especially in remote area could help reduce the complications there by reducing ICU admission. Maternal morbidity and mortality in such cases can be further minimized significantly by early assessment and aggressive intervention by a team work involving obstetricians, intensivists and anaesthetist.

\section{Funding: No funding sources} Conflict of interest: None declared

Ethical approval: The study was approved by the Institutional Ethics Committee

\section{REFERENCES}

1. Why mother die: Reported on confidential enquiries into maternal death in United Kingdom 2000-2002. LONDON: RCOG Press, 2004

2. Mabie WC, Sibai BM. Treatment in an obstetric intensive care unit. Am J Obstet Gyneco.1990;162:14

3. Johanson RB, A nthony J, Dommisse J. Obstetric Intesive care Groote schuur hospital, Cape Town. J Obstet Gynaecol.1995;15:174-7.

4. Visser W, Wallenger HCS. Maternal and Perinatal outcome of temporizing management in 254 cinsecutive patients with severe preeclampsia remote from. Eur J Obstet Gynaecol Reprod Bio. 1995;6: 156-60.

5. Ruiz AA U, Martinen HC, Seucl F, Ferez LAS, Trista RV, Saezhe M. Compartmeno de la enfermeded, Obstetrica grave. Neaeve Anos en una Unidad de Gudo, Sos Intenivas Medi. 2003;6:18.

6. Waterstone M, Bweley S Wolfe C. Incidence and predictors of severe obstetric morbidity: Case control study. BM J. 2001;322:1089-94.

7. Okonofua FE. Reproductive health and development in Africa. Afr J Report Health. 1997;2:1.

8. Kilpatric SJ, Mathay MA. Obstetric patients requiring critical care: A five-year review. Chest 1992;101:1407-12.

9. Lapinsky SE, Kruczyski K, Seaward GR, Farine D, Cerosssman RF. Critical care management of obstetric patients. Can J Anaesth. 1997;44:325-9.

10. Graham SG, Luxton MC. The requirement for intensive care support for the pregnant population Anaesth 1987;44:581-4.

11. Collop NA, Sahn SA. Critical care illness in pregnancy. Chest 1993;103:1548-52.

12. Monaco TJ Jr, Spielman FJ, Katz VL. Pregnant patients in intensive care unit: A descriptive analysis. South Med. 1993;86:414-17.

13. Hazelgrove JF, Price C, Pappachan VJ, Smith GB. Multicentre study of obstetric admission to 14 intensive care units in southern England. Crit Care Med. 2001;29:770-5.

14. Umo E, Lumley J, Hold Croft A. Critically ill parturient women and admission to intensive care: A 5year review. Int J Obstet Anaesth 1996;5:79-84.

15. Munnur U, Karnad DR, Bandi VD, Lapsia V, Suresh MS, Ramshesh P, Gardner MA et al. Critically ill obstetric patients in an American and Indian public hospital: Comparison of care mix, organ dysfunction, intensive care and outcome. Intensive Care Med 2005;31:1078-94.

16. Irene YV, Vaneet K, Gurvinder K, Arun A, Lalita A. Critical care in obstetrics-scenario in a developing country. J Obstet Gynecol India. 2008;58(3):217-0.

17. Ashraf N, Mishra SK, Kundra P, Veena P, Soundaraghavan S, Habeebullah S. Obstetric patients requiring intensive care: a one year retrospective study in a tertiary care institute in India. Anesthesiology research and practice. 2014. 
18. Wanderer JP, Leffert LR, Mhyre JM, Kuklina EV, Callaghan WM, Bateman BT. Epidemiology of obstetric-related intensive care unit admissions in Maryland: 1999-2008. Critical care medicine. 2013 ;41(8):1844.

19. Stevens TA, Carroll MA, Promecene PA, Seibel M, Monga M. Utility of Acute Physiology, Age, and Chronic Health Evaluation (APACHE III) score in maternal admissions to the intensive care unit. American Journal of Obstetrics and Gynecology. 2006;194(5):e13-5..

20. Zwart JJ, Dupuis JR, Richters A, Öry F, van Roosmalen J. Obstetric intensive care unit admission: a 2-year nationwide population-based cohort study. Intensive care medicine. 2010;36(2):256-63.

21. Tang LC, Kwok AC, Wors AY, Lee YY, Sun KU. Critical care in obstetrical patients: an eight year review. Care Med J (Eng) 1997;110:936-41.

22. Mahatte NG, Murphy Kaulbeck L, Le Q. Obstetric admission to the intensive care unit. Obstet Gynecol 19997;94:263-6.

Cite this article as: Garg P, Tripathi U. A study to know clinical characteristics and outcome of obstetrics patients requiring ICU admission. Int J Reprod Contracept Obstet Gynecol 2018;7:2639-44. 